\title{
ЕЛЕКТРИЧНИЙ МЕТОД ВИМІРЮВАННЯ ВОЛОГОСТІ БІОМАСИ ОЛІЙНИХ ЛУБЯНИХ КУЛЬТУР
}

\author{
S. YAHELYUK, V. DIDUKH \\ Lutsk National Technical University
}

\section{THE ELECTRICAL METHOD FOR MEASURING THE MOISTURE CONTENT OF THE OILSEED BAST BIOMASS}

\section{https://doi.org/10.36910/6775-2310-5283-2022-15-26}

Мета. Розробка та випробування методу визначення вологості з допомогою спеціально розробленого пристосування, принщип дї якого заснований на вимірюванні електричного опору біомаси олійних луб'яних культур

Методика. Дослідження проводили в лабораторних та польових умовах; використовувалися стандартні та спеціально розроблені прилади та пристрої.

Результати. Вологість біомаси олійних луб'яних культур є важливим фактором під час оцінки якості та визначення придатності для переробки. Як правило, вологість біомаси під час збирання врожаю становить 15-65\%. Нормативно-технічні документи вказують допустиме значення вологості у межах 19\%. Стандартний метод визначення заснований на висушуванні біомаси до сталої маси з подальшим розрахунком значення вологості. Проте даний метод потребує багато часу та стачіонарних умов проведення. У статті запропоновано пристрій для вимірювання вологості біомаси олійних луб'яних культур. Принцип дії заснований на вимірюванні електричного опору проби біомаси. Метод та пристрій були перевірені иляхом порівняння результатів вимірювань вологості біомаси льону олійного та льону-довгуния з допомогою розробленого пристрою та стандартним методом сушіння. Запропоновано використовувати метод визначення вологості для оцінки якості біомаси льону олійного, льону-довгуния, конопель та ін.

Практична значимість. Метод визначення вологості, заснований на вимірюванні електричного опору проби біомаси має переваги щуодо стандартного методу визначення вологості: мобільність, економічність, ергономічність. Він може бути застосований як у умовах лабораторії, так $i$ у польових умовах. Може бути рекомендований для використання сільськогосподарськими підприємствами та наукових досліджень

Ключові слова: Вологість, біомаса, олійні луб'яні культури, вимірювання, опір 
Постановка проблеми у загальному вигляді та її зв'язок з важливими науковими та практичними завданнями. На сьогодні в світі спостерігається тенденція зростання наукового інтересу до вдосконалення виробництва олійних луб'яних культур та переробки їх залишків. Особливо це прослідковується у публікаціях індійських $[1,2]$ та французьких вчених [3, 4]. Найбільш результативним вважається комплексний підхід - тобто використання всієї рослини - насіння, лушпиння, стебла, макухи, тощо. Однак, встановлено [5-7], що луб'яні культури, хоча і мають багато спільних властивостей, проте природні умови, в яких формується рослина, суттєво впливають на можливості її подальшого використання. Так, B. S. Prithwiraj Dey зі співавторами, у своїй роботі показали, що субтропічний льон часто стикається з гострою проблемою вилягання через сильні вітри у поєднанні 3 дощами під час дозрівання. Ю. І. Онюх, І. В. Тараймович визначили, що умови вирощування льону олійного відрізняються у різних регіонах України. Це приводить до відмінностей у властивостях та характеристиках отриманого врожаю.

Проте, незалежно від місця вирощування, у всіх культур $є$ спільна характеристика, яка є критичним фактором якості отриманого врожаю вологість. В зв'язку з тим, що вона залежить від атмосферних умов, в яких знаходиться рослинна біомаса, у стандартах передбачені норми відносної вологості й температури повітря, за яких витримують зразки та проводять фізико-механічні дослідження матеріалів. Для льону олійного та льонудовгунця, наприклад, згідно ДСТУ 4149:2003 «Треста лляна. Технічні умови»це відносна вологість $65 \%$ і температура повітря $20^{\circ} \mathrm{C}$. Також визначають нормовану вологість соломи - 19\% (до абсолютно сухої маси), якщо вологість перевищує $25 \%$, то таку сировину не приймають. Внаслідок зміни вологості, властивості біомаси настільки сильно змінюються, що ऑii не можна не враховувати у виробництві та під час наукових досліджень.

На сьогодні розроблено та використовується багато методів, що дозволяють виміряти вологість біомаси олійних луб'яних культур, проте, вони потребують складного та дорогого обладнання (переносні вологоміри), енергетично затратні та вимагають багато часу (метод сушіння) або налаштовані на одну культуру (насіннєві експрес-вологоміри). Також точність та відтворюваність результатів окремих методів та обладнання недостатня. Отже, розробка сучасних методів для визначення вологості біомаси олійних луб'яних культур є дуже важливим. 
Аналіз останніх досліджень, у яких започатковано вирішення проблеми. Відповідно до раніше проведених досліджень В. Ф. Дідуха, С. В. Ягелюк, А. О. Тіхосової, [8-10] придатність до подальшої переробки залежить від багатьох ознак біомаси стебел луб'яних культур. Також встановлено, що на даному етапі економічного розвитку країни, найбільш доцільним є використання такої біомаси для виготовлення твердого та рідкого біопалива [11]. Г.Г. Гелетуха та ін. дослідили потенціал залишків сільськогосподарських рослин (біомаси) для виробництва енергії в Україні. В [12] досліджені властивості та показані результати використання малогабаритних паливних рулонів з залишків збирання насіння льону олійного. Українські вчені досліджували придатність до подальшої переробки біомаси льону олійного, льону-довгунця, конопель та інших культур [13, 14]. Встановлювали основоположні властивості луб'яних культур, та фактори, що впливають на їх формування [5]. Визначали основні відмінності льону, вирощеного у різних кліматичних умовах України [6, 7]. Встановлено, що висота льону олійного, вирощеного на півдні України, а саме в сухих та теплих кліматичних умовах, не перевищує 45-50 см до збирання. За використання сучасних технологій після збирання утворюється суха, сплутана біомаса стебел льону олійного [15]. У вологих та прохолодних кліматичних умовах Західного Полісся льон олійний має довге (інколи більше 100 см) та міцне стебло. Після відділення насіння, утворює вологу стеблову масу, яку можливо перетворити в тресту. Вологість вихідної сировини спричиняє необхідність застосування різних технологій збирання. Адже результати, викладені у роботі [15] показують, що зусилля різання для стебел льону олійного та льону-довгунця 3 різною вологістю суттєво відрізняються.

Результати проаналізованих досліджень [15-17] доводять, що вологість важливий показник, який визначає можливості подальшої переробки біомаси олійних луб'яних культур. Тому $\epsilon$ необхідність у розробці методів та пристосувань, які дозволять проводити дослідження вологості біомаси олійних луб'яних культур у польових та лабораторних умовах.

Виклад основного матеріалу 3 повним обгрунтуванням отриманих наукових результатів. Поставлена задача розробки ефективного методу вимірювання вологості біомаси олійних луб'яних культур з варіантами його застосування (в лабораторних або польових умовах). Ще однією умовою $\epsilon$ можливість розробки варіантів для біомаси різних сільськогосподарських культур. Для досліджень використані сорти льону-довгунця та льону олійного, 
які були зібрані у ДПЕГ «Еліта» Волинської ДСГСДС ІК НААН, смт Рокині. У таблиці 1. подана їх характеристика. Дані отримані за результатами досліджень протягом 2019-2021 pp. Варіанти для проведення дослідів з біомасою льону олійного та льону-довгунця відбирались на полях господарства із врожаю 2019-2021 років.

\section{Таблиця 1. Характеристика стеблостою льону-довгунця}

\begin{tabular}{|c|c|c|c|c|c|c|c|}
\hline \multirow{2}{*}{$\begin{array}{c}\text { Назва сорту/ } \\
\text { характеристика }\end{array}$} & \multicolumn{3}{|c|}{ Льон-довгунець } & \multicolumn{4}{|c|}{ Льон олійний } \\
\hline & Глінум & Есмань & $\begin{array}{c}\text { Гладіа- } \\
\text { тор }\end{array}$ & $\begin{array}{c}\text { Південна } \\
\text { ніч } \\
\end{array}$ & Айсберг & Орфей & $\begin{array}{c}\text { Водо- } \\
\text { грай }\end{array}$ \\
\hline $\begin{array}{l}\text { Вегетаційний } \\
\text { період, днів }\end{array}$ & $72-76$ & $82-87$ & $72-77$ & $88-90$ & $86-88$ & $87-90$ & $87-89$ \\
\hline $\begin{array}{l}\text { Технічна } \\
\text { довжина стебла, } \\
\text { м }\end{array}$ & 88,5 & 82,5 & 78,8 & $70,0-76,5$ & $48,0-60,0$ & $\begin{array}{c}50,0- \\
61,0\end{array}$ & $\begin{array}{r}53,0- \\
60,0\end{array}$ \\
\hline Вміст волокна, \% & $29-32$ & $29,1-30,5$ & 27,3 & $14,6-20,0$ & $15,6-22,6$ & $\begin{array}{c}15,1- \\
24,6\end{array}$ & $\begin{array}{c}15,9- \\
22,7\end{array}$ \\
\hline $\begin{array}{l}\text { Вихід довгого } \\
\text { волокна, \% }\end{array}$ & $\begin{array}{l}20,5- \\
23,7\end{array}$ & $20,2-23,5$ & $20,2-21,4$ & $88,0-90,0$ & $86,0-88,0$ & $\begin{array}{l}87,0- \\
90,0\end{array}$ & $\begin{array}{l}87,0- \\
89,0\end{array}$ \\
\hline \multicolumn{8}{|c|}{ Врожайність, т/га } \\
\hline a) соломи & $6,0-8,0$ & $6,4-7,8$ & $6,0-8,0$ & $3,6-4,8$ & $2,9-3,6$ & $2,8-3,5$ & $2,0-2,4$ \\
\hline б) волокна & $1,7-2,4$ & $1,8-2,1$ & $1,9-2,3$ & $0,4-0,7$ & $0,5-1,0$ & $0,6-0,9$ & $0,5-0,7$ \\
\hline в) насіння & $0,55-0,69$ & $0,55-0,87$ & $0,65-0,75$ & $1,3-1,7$ & $1,6-1,9$ & $1,6-1,8$ & $1,8-2,1$ \\
\hline Олійність, \% & - & - & - & $44-46$ & $47-49$ & $47-48$ & $48-49$ \\
\hline
\end{tabular}

Вологість - це показник відношення маси води, що знаходиться в матеріалі, до загальної маси досліджуваного зразка, виражений у відсотках. Визначення вологості для біомаси олійних луб'яних культур проводили в лабораторних умовах Луцького національного технічного університету. Для отримання контрольних результатів визначали вологість методом сушіння. Для цього відібраний й подрібнений зразок масою 5-6 г закладали в алюмінієві бюкси, попередньо просушені і протаровані, закривали їх кришкою й важили на технічних вагах з точністю до 0,01 г $[5,16]$. Після цього бюкси із відкритими кришками поміщали в нагріту до $100 \pm 5^{\circ} \mathrm{C}$ сушильну шафу СП-30. Сушіння проводили до постійної ваги, яка встановлювалася періодичним зважуванням після 20, 40, 60, 80, 100, 120 хв до постійної ваги. 
Перед кожним зважуванням бюкси, вийняті із сушильної шафи, поміщали в ексикатор для охолодження до кімнатної температури. Аналогічно проводили дослідження при температурі $125,150{ }^{\circ} \mathrm{C}$. Дослідження проводили одночасно для трьох наважок. Результати вимірювань обробляли математикостатистичними методами [18].

Запропонований пристрій (рис.) складається з ізолюючої підложки 1 , на яку вкладається шар біомаси досліджуваної рослини, у даному випадку льону олійного 3, затискачів-контактів 2, що безпосередньо взаємодіють зі стеблами, 3'єднувальних дротів і цифрового мегомметра 4. В подальшому планується використання сучасних приладів 3 можливістю друку результатів. Принцип дії грунтується на вимірюванні зміни електричного опору шару біомаси рослин.

Для перевірки методу в лабораторних умовах здійснювали калібрування пристрою. Для цього підготовлювали пробу біомаси стебел льону олійного одного сорту, діаметру, стиглості. На ізолюючу підложку 1 накладали відібрану пробу біомаси стебел 3 шаром в одне стебло. За допомогою затискачівконтактів 2 шар стебел приєднувався до мегомметра 4. Таким способом утворене замкнене електричне коло й покази приладу показували опір біомаси стебел льону олійного за вологості в даний момент часу. Показники записували в журнал.

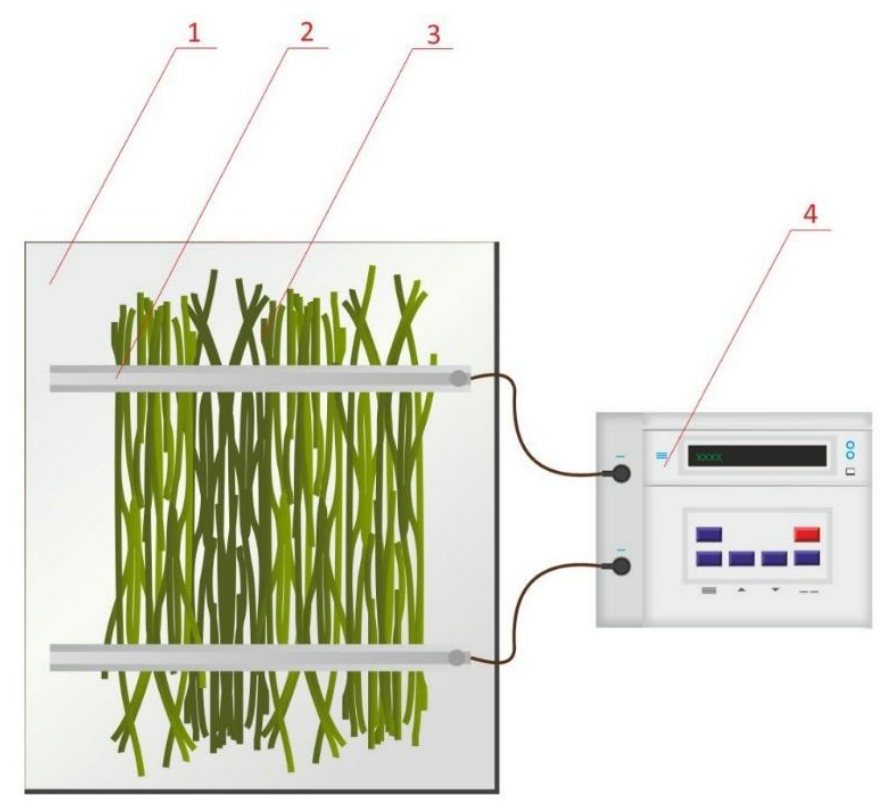

Рис. 1. Схема пристрою для вимірювання вологості біомаси льону олійного: 1 - ізолююча підложка; 2 - контакти-затискачі; 3 -біомаса стебел льону олійного; 4 - цифровий мегомметр 
Відразу після вимірювання електричного опору проводили зважування проби. Результати також занотовували. Вимірювання проводили через кожні 10 годин до повного висихання проби біомаси. Опір переставав змінюватись, коли проба біомаси стебел висихала. Пробу знову зважували.

Для кожного етапу вимірювань досліди проводилися по 5 разів. Далі складали градуювальні таблиці (таблиця 2). Цей метод використовували для експрес визначення вологості біомаси льону олійного та льону-довгунця в польових умовах.

\section{Таблиця 2. Залежність опору біомаси стебел льону олійного від вологості}

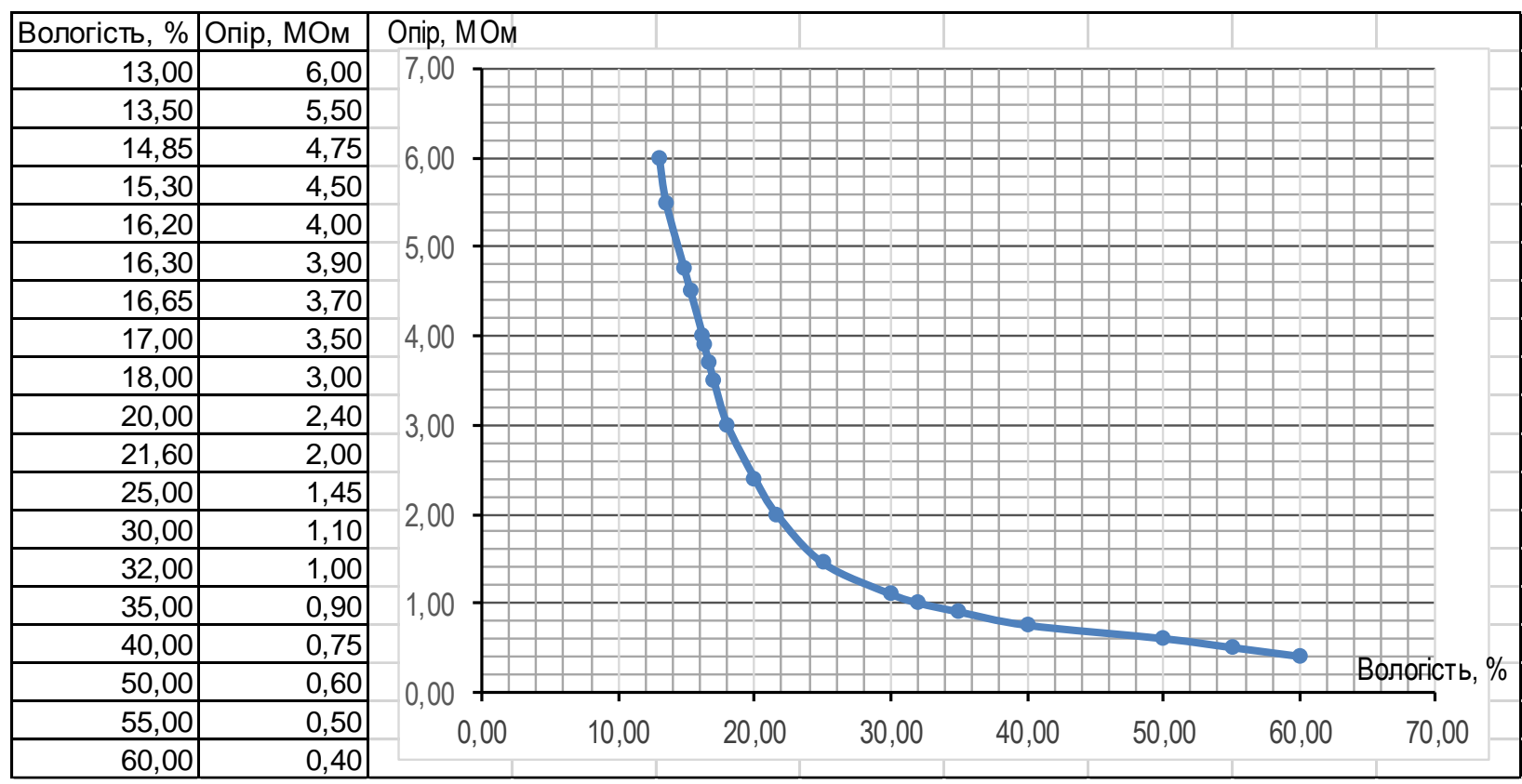

Досліджували біомасу стебел сортів льону олійного Орфей, Південна ніч, Айсберг, Водограй та льону-довгунцю Гладіатор, Глінум, Есмань. Для кожного досліду відбирали пробу біомаси з однієї ділянки поля. Стеблостій однорідний. Фаза стиглості - рання жовта. Отримані експериментальні дані оброблялися відомими статистичними методами [18], а також за допомогою програми Microsoft Excel. Вони характеризуються коефіцієнтом варіації v від $\pm 1,1 \%$ до $\pm 3,2 \%$ та похибкою досліду $0,8 \%$.

В таблиці 3 подані результати визначення вологості біомаси льону олійного відразу після збирання у польових умовах та після одноденного вилежування в умовах лабораторії. Для тих самих проб біомаси також визначали вологість методом сушіння. Порівняння масиву результатів у таблиці 3 доводить можливість використання методу визначення вологості біомаси 
олійних луб’яних культур, заснованого на вимірюванні їі електричного опору для практичного використання.

Таблиця 3. Вологість стебел льону

\begin{tabular}{|l|c|c|c|c|}
\hline \multirow{2}{*}{ Сорт } & \multicolumn{4}{|c|}{ Вологість стебел, \% } \\
\cline { 2 - 5 } & $\begin{array}{c}\text { В польових } \\
\text { умовах, } \\
\text { відразу після } \\
\text { збирання }\end{array}$ & $\begin{array}{c}\text { В лабораторних } \\
\text { умовах після } \\
\text { одноденного } \\
\text { вилежування }\end{array}$ & Метод сушіння \\
\hline Орфей & 50,0 & 50,2 & 16,4 & 16,2 \\
\hline Південна ніч & 55,0 & 54,8 & 14,8 & 14,6 \\
\hline Айсберг & 60,0 & 59,7 & 15,6 & 15,6 \\
\hline Гладіатор & 53,0 & 52,8 & 17,0 & 17,2 \\
\hline Глінум & 55,0 & 55,2 & 19,4 & 19,0 \\
\hline Водограй & 62,0 & 60,5 & 20,4 & 20,8 \\
\hline Есмань & 56,0 & 56,8 & 19,8 & 19,3 \\
\hline
\end{tabular}

Розроблений метод вимірювання вологості мобільний та простий у використанні. Тому його можна запропонувати для сільськогосподарських підприємств. Метод та пристрій можуть застосовуватись під час збирання врожаю для визначення придатності біомаси олійних луб'яних культур до переробки у тверде біопаливо, тресту і т.д. Також з допомогою даного методу можна визначати вологість під час проведення наукових досліджень.

Висновки та перспективи подальших досліджень. В результаті проведених досліджень підтверджено важливість вологості, як критерію оцінки якості та придатності до подальшої переробки біомаси олійних луб'яних культур.

В статті запропоновано пристрій для вимірювання вологості біомаси олійних луб'яних культур. Принцип дії заснований на вимірюванні електричного опору проби біомаси. Пристрій складається із ізолюючої підложки, на яку вкладається шар біомаси, затискачів-контактів, з'єднувальних дротів і цифрового мегомметра. Метод та пристрій були перевірені шляхом порівняння результатів вимірювань вологості біомаси льону олійного та льонудовгунця 3 допомогою розробленого пристрою та стандартним методом сушіння. Порівняння результатів дослідження вологості зразків біомаси льону олійного та льону-довгунця 3 допомогою розробленого методу та методом сушіння доводить можливість його використання для практичних цілей. 


\section{Список використаних джерел}

1. Prithwiraj Dey, B.S. Mahapatra, Biswajit Pramanick, Suhita Pyne, Pramit Pandit, Optimization of seed rate and nutrient management levels can reduce lodging damage and improve yield, quality and energetics of subtropical flax, Biomass and Bioenergy, Volume 157, 2022, DOI: 10.1016/j.biombioe.2022.106355,

2. Abd-Rabboh, AMK, Mazrou, Y, El-Borhamy, AMA, Abdelmasie, HWKL, Hafez, Y, Abdelaal, KA. Effect of sowing dates and seed rates of flax intercropped with sugar beet on productivity of both crops and competitive relationships. Rom Biotechnol Lett . 2021; 26(6): 30743089. DOI: $10.25083 / \mathrm{rbl} / 26.6 / 3074-3089$

3. Grégoire, M. Barthod-Malat, B. Labonne, L. Evon, P. Luycker, E. De P. Ouagne, Investigation of the potential of hemp fibre straws harvested using a combine machine for the production of technical load-bearing textiles, Industrial Crops and Products, Volume 145, 2020, 111988, Official URL: https://doi.org/10.1016/j.indcrop.2019.111988

4. D. Calzolari, G. Magagnini, L. Lucini, G. Grassi, G.B. Appendino, S. Amaducci, High added-value compounds from Cannabis threshing residues, Industrial Crops and Products, Volume 108, 2017, Pages 558-563

5. Байдакова Л. І., Ягелюк С. В., Байдакова І. М. Експертиза товарів : підручник. Київ : Видавничий Дім «Слово», 2014. 380 с.

6. Онюх Ю. Особливості вирощування льону олійного в умовах Західного Полісся. Подільський вісник: сільське господарство, техніка, економіка. Сільсько-господарські науки, 2017, 27, 37-43.

7. Дідух В.Ф., Онюх Ю.М., Тараймович І.В. Дослідження умов вирощування льону олійного. Сільськогосподарські машини, 2016, 34, 104-110.

8. Ягелюк С. В., Дідух В.Ф. Концептуальна модель технологій переробки стебел льону. Сільськогосподарські машини. 2020, 44, 155-164

9. Ягелюк С. В., Дідух В.Ф. Напрямки використання продукції переробки льону олійного та льону-довгунця. Товарознавчий вісник, 2020, 13, 292-305

10. Тіхосова А. О., Богданова О.Ф., Забродіна О.С., Товарознавча оцінка якості целюлози на основі ненаркотичних конопель для застосування іiі на паперових підприємствах. Товарознавчий вісник, 2019, 1(12), 221-228.

11.Гелетуха Г.Г., Желєзна Т.А., Жовмір М.М., Матвєєв Ю.Б., Дроздова О.І.. Оцінка енергетичного потенціалу біомаси в Україні. Частина 1. Відходи сільського господарства та деревна біомаса Промышленная теплотехника. 2010, 32, 6, 58-65.

12. Yaheliuk, S., Didukh, V., Busnyuk, V., Boyko, G., Shubalyi, O. Optimization on Efficient Combustion Process of Small-Sized Fuel Rolls made of Oleaginous Flax Residues. INMATEH Agricultural Engineering 2020, 62(3), 361-368

13. Безуглий, М., Гриник, I., \& Булгаков, В. Науково практичні підходи до використання соломи та рослинних решток. Вісник аграрної науки, 2010, 3, 5-8.

14. The improved technology of biomass processing to obtain products of various applications. S.Yaheliuk, V.Didukh, G.Boyko. Agricultural machines. 2020, 45, 155-164

15. Ягелюк С.В., Дідух В.Ф., Артюх Т.Н., Голій О.В. Зусилля різання біомаси олійних луб'яних культур з урахуванням вологості. Сільськогосподарські машини, 2021, 46, 124-132

16. Julrat, S. Trabelsi, S. Portable Six-Port Reflectometer for Determining Moisture Content of Biomass Material, IEEE Sensors Journal, 2017, 17(15), 4814-4819

17. Nielsen, N. P. K., Felby, C. Poulsen, T. and Gardner, D. J. Importance of temperature, moisture content, and species for the conversion process of wood residues into fuel pellets, Wood Fiber Sci., 2009, 44 (43), 414-425 
18. Хайліс Г.А., Коновалюк Д. М. Основи проектування і дослідження сільськогосподарських машин. К.: НМК ВО, 1992, 320 с.

\section{Reference}

1. Prithwiraj Dey, B.S. Mahapatra, Biswajit Pramanick, Suhita Pyne, Pramit Pandit, Optimization of seed rate and nutrient management levels can reduce lodging damage and improve yield, quality and energetics of subtropical flax, Biomass and Bioenergy, Volume 157, 2022, DOI: 10.1016/j.biombioe.2022.106355,

2. Abd-Rabboh, AMK, Mazrou, Y, El-Borhamy, AMA, Abdelmasie, HWKL, Hafez, Y, Abdelaal, KA. Effect of sowing dates and seed rates of flax intercropped with sugar beet on productivity of both crops and competitive relationships. Rom Biotechnol Lett . 2021; 26(6): 30743089. DOI: $10.25083 / \mathrm{rbl} / 26.6 / 3074-3089$

3. Grégoire, M. Barthod-Malat, B. Labonne, L. Evon, P. Luycker, E. De P. Ouagne, Investigation of the potential of hemp fibre straws harvested using a combine machine for the production of technical load-bearing textiles, Industrial Crops and Products, Volume 145, 2020, 111988, Official URL: https://doi.org/10.1016/j.indcrop.2019.111988

4. D. Calzolari, G. Magagnini, L. Lucini, G. Grassi, G.B. Appendino, S. Amaducci, High added-value compounds from Cannabis threshing residues, Industrial Crops and Products, Volume 108, 2017, Pages 558-563

5. Baydakova L. I., Yahelyuk S. V., Baydakova I. M. Ekspertyza tovariv : pidruchnyk. Kyyiv: Vydavnychyy Dim «Slovo», 2014, 380 s.

6. Onyukh Y U. Osoblyvosti vyroshchuvannya l'onu oliynoho $\mathrm{v}$ umovakh Zakhidnoho Polissya. Podil's'kyy visnyk: sil's'ke hospodarstvo, tekhnika, ekonomika. Sil's'ko-hospodars'ki nauky, 2017, 27, 37-43.

7. Didukh V. F., Onyukh YU. M., Taraymovych I. V. Doslidzhennya umov vyroshchuvannya l'onu oliynoho. Sil's'kohospodars'ki mashyny, 2016, 34, 104-110.

8. Yahelyuk S. V., Didukh V. F. Kontseptual'na model' tekhnolohiy pererobky stebel l'onu. Sil's'kohospodars'ki mashyny, 2020, 44, 155-164

9. Yahelyuk S. V., Didukh V. F. Napryamky vykorystannya produktsiyi pererobky l'onu oliynoho ta l'onu-dovhuntsya. Tovaroznavchyy visnyk, 2020, 13, 292-305

10. Tikhosova A. O., Bohdanova O. F., Zabrodina O. S., Tovaroznavcha otsinka yakosti tselyulozy na osnovi nenarkotychnykh konopel' dlya zastosuvannya yiyi na paperovykh pidpryyemstvakh. Tovaroznavchyy visnyk, 2019, 1(12), 221-228.

11. Heletukha H.H., Zhelyezna T.A., Zhovmir M.M., Matvyeyev YU.B., Drozdova O.I. Otsinka enerhetychnoho potentsialu biomasy v Ukrayini. Chastyna 1. Vidkhody sil's'koho hospodarstva ta derevna biomasa Promyshlennaya teplotekhnyka. 2010, 32, 6. 58-65

12. Yaheliuk, S., Didukh, V., Busnyuk, V., Boyko, G., Shubalyi, O. Optimization on Efficient Combustion Process of Small-Sized Fuel Rolls made of Oleaginous Flax Residues. INMATEH Agricultural Engineering 2020, 62(3), 361-368

13. Bezuhlyy, M., Hrynyk, I., \& Bulhakov, V. Naukovo praktychni pidkhody do vykorystannya solomy ta roslynnykh reshtok. Visnyk ahrarnoyi nauky, 2010, 3, 5-8.

14. The improved technology of biomass processing to obtain products of various applications. S.Yaheliuk, V.Didukh, G.Boyko. Agricultural machines. 2020, 45, 155-164

15. Yahelyuk S.V., Didukh V.F., Artyukh T.N., Holiy O.V. Zusyllya rizannya biomasy oliynykh lub'yanykh kul'tur z urakhuvannyam volohosti. Sil's'kohospodars'ki mashyny, 2021, 46, 124-132

16. Julrat, S. Trabelsi, S. Portable Six-Port Reflectometer for Determining Moisture Content of Biomass Material, IEEE Sensors Journal, 2017, 17(15), 4814-4819 
17. Nielsen, N. P. K., Felby, C. Poulsen, T. and Gardner, D. J. Importance of temperature, moisture content, and species for the conversion process of wood residues into fuel pellets, Wood Fiber Sci., 2009, 44 (43), 414-425

18. Khaylis H. A., Konovalyuk D. M. Osnovy proektuvannya i doslidzhennya sil's'kohospodars'kykh mashyn. K.: NMK VO, 1992, 320 s.

Goal. Goal. Design and testing of the Method for Measuring Moisture using a specially designed device, is based on measuring the electrical resistance of the biomass of Oilseed Bast Crops

Method. The research was carried out in laboratory conditions and in production; standard and specially designed devices and devices were used.

Results. The moisture content of Oilseed Bast Crops is an important factor in assessing quality and determining suitability for processing. As a rule, the moisture content of biomass at harvest is $15-65 \%$. Normative and technical documents indicate the permissible value of moisture content within 19\%. The normative determination method is based on drying the biomass into a stable mass and then calculating the moisture value. However, this method requires a lot of time and stationary conditions. The article proposes a device for Measuring the Moisture content of the biomass of Oilseed Bast Crops. The operating principle is based on measuring the electrical resistance of a biomass sample. The method and device were verified by comparing the moisture content of Oilseed Flax and Fiber Flax biomass using the developed device and the normative drying method. It is proposed to use the moisture determination method to assess the quality of the biomass of oil flax, fiber flax, hemp, etc.

Practical significance. The Method for Measuring Moisture based on measuring the electrical resistance of a biomass sample has advantages over the normative moisture determination method: mobility, economy, ergonomics. It is applicable both in the laboratory and in the field. Can be recommended for use by agricultural enterprises and scientific research

Keywords: Moisture content, biomass, Oilseed Bast Crops, measurement, resistance 